\title{
Value of mountain rye for suppression of annual bromegrasses on semiarid mined lands
}

\author{
MYRON R. ANDERSEN, EDWARD J. DEPUIT, ROLLIN H. ABERNETHY, AND \\ LARRY H. KLEINMAN
}

\begin{abstract}
Authors are former graduate research assistant in agronomy. professor of range management, and professor of plant science, Department of Range Management and Department of Plant, Soil and Insect Sciences, University of Wyoming, Box 3354, Laramie 82071; and plant ecologist, Kiewit Mining Group, Inc., Sheridan, Wyo. 82801, respectively.
\end{abstract}

\begin{abstract}
The value of mountain rye (Secale montanum Guss.) for competitive suppression of 2 annual bromegrasses (downy brome, Bromus tectorum L. and Japanese brome, B. japonicus Thunb) was investigated in a 3-year study on reclaimed coal mined lands in southeastern Montana. Rye established rapidly and vigorously, but did not persist appreciably (either through initially established plants or new seedlings) after the second year. However, mountain rye significantly reduced growth and reproduction of annual bromes during the first 2 growing seasons. Mountain rye also inhibited growth of other concurrently seeded perennial grasses during the first 2 seasons. Annual brome soil seedbanks were not sufficiently reduced in rye-seeded plots to prevent an eventual, third year recovery of brome productivity after a massive dieback of rye between the second and third growing seasons. Mountain rye therefore proved effective for short but not for longer-term control of annual bromes. This study did not allow distinction between the known short-lived nature of mountain rye and/or local environment as causal factors for the massive dieback after the second year.
\end{abstract}

Key Words: mineland revegetation, weed control, plant competition, Secale montanum G., Bromus tectorum L., Bromus japonicus Thunb.

Downy brome (Bromus tectorum L.) and Japanese brome ( $B$. japonicus Thunb.) have become dominant invading species over vast areas of rangelands in the western United States (Mack 1981, Hulbert 1955, Stewart and Hull 1949). Both downy and Japanese bromes exhibit winter-annual phenology: vigorous early season growth and high reproductive ability. These features result in competition for establishment and growth of desirable perennial species on rangelands (Evans 1961, Evans et al. 1970, Harris 1967, Harris and Wilson 1970). During disturbed land reclamation, severe brome infestations can restrict perennial species establishment, slow the rate of and, possibly, alter the trajectory of secondary succession (Allen 1989, Allen and Knight 1984).

Past work has demonstrated marginal revegetation success on range sites with high annual brome densities unless steps are taken to reduce brome infestation (Evans et al. 1970). An addition to the direct brome control measures of mechanical, burning, or herbicidal treatments involves introducing vigorous companion species to biologically retard bromes through competitive interference (Monsen and Turnipseed 1990, Evans et al. 1970).

\footnotetext{
The funding, technical, and cooperative support of Kiewit Mining Group, Inc., Decker Coal Co., and Big Horn Coal $\mathrm{Co}$. for this research is gratefully acknowledged. This is JA 1667 of the Wyoming Agricultural Experiment Station. Manuscript accepted 4 November 1991.
}

Mountain rye (Secale montanum Guss.) is a short-lived, coolseason perennial bunchgrass native to the middle east and northern Africa (Stutz 1972). It has been used effectively in southern Idaho for suppression of downy brome (Monsen and Shaw 1984). Buman and Abernethy (1988) found little post-harvest seed dormancy for the species with high germination at cool and widely fluctuating temperatures, indicating a potential for fall germination concurrent with annual bromes. Mountain rye also demonstrated greater root and shoot growth than downy brome when both species were established together at equal densities in growth chambers (Buman et al. 1988), suggesting that rye may have superior competitive ability.

This study was conducted to determine the effectiveness of mountain rye for suppression of annual bromes when planted as a companion crop with other perennial species on a reclaimed coal surface-minesite in southeastern Montana. The hypotheses tested were that mountain rye would: (1) establish rapidly and exhibit vigorous growth concurrent with downy and Japanese bromes, (2) competitively reduce growth and reproduction of these bromes for a sufficient time to allow depletion of the soil seedbank, and (3) eventually decline, due to its short-lived nature, allowing other seeded perennials to fully occupy the site after reduction of brome competition.

\section{Methods and Procedures}

\section{Study Area}

The study was conducted at the Decker Coal Mine, a large surface mining operation in southeastern Montana $32 \mathrm{~km}$ north of Sheridan, Wyo., at an elevation of 1,036 to 1,219 m. Annual precipitation averages $300 \mathrm{~mm}$, nearly half of which occurs from April through June. Native soils are predominantly loams and silty clay loams with alkaline reaction, and originate from sedimentary parent material. Native rangeland vegetation is a mosaic of northern mixed prairie, sagebrush steppe, and ponderosa pine savannah communities, as generally described by Payne (1973). Dense stands of both downy and Japanese bromes occur on degraded range sites throughout the area. The reclamation goal at the Decker Mine is re-establishment of rangeland vegetation dominated by native perennial grasses, forbs, and shrubs for livestock grazing and wildlife habitat.

The study site was selected in September 1986 on mine spoils graded to an approximate $4 \%$ south-facing slope. Spoils were covered with $46 \mathrm{~cm}$ of $C$ horizon subsoil, followed by application of $15 \mathrm{~cm}$ of A-B horizon topsoil hauled immediately to the site following salvage on native range. Texture of both topsoil and subsoil was loamy, with $\mathrm{pH}$ ranging from 7.7 (topsoil) to 8.1 (subsoil). Annual precipitation was 273, 223, and $301 \mathrm{~mm}$ during the growing seasons of 1987,1988 , and 1989, respectively. Below- 
average precipitation in 1988 was accompanied by greatly aboveaverage temperatures from June through August, resulting in severe drought conditions. Additional detail on both weather and study site soil characteristics can be found in Andersen (1989).
Experimental Design and Treatments
Three main treatment variables were applied to the study site:
1) perennial species mixture seeding rate: $\quad 0$ and $25.2 \mathrm{~kg} \mathrm{PLS} / \mathrm{ha}$
2) mountain rye seeding rate: $0,11.2$ and $22.4 \mathrm{~kg} P L S /$ ha
3) annual (downy + Japanese)
brome seeding rate:
$0,2.8$ and $5.6 \mathrm{~kg} \mathrm{PLS} / \mathrm{ha}$

All 18 treatment combinations ( 2 perennial mixture rates $X 3$ rye rates $\mathrm{X} 3$ brome rates) were established in each of the 3 replications using a partially randomized, split-split block experimental design (Andersen 1989). Each individual treatment combination subsubplot measured 11.0 by $6.1 \mathrm{~m}$. The 3 seeding rates of rye (providing 0,89 , and 178 live seeds $/ \mathrm{m}^{2}$ ) and annual bromes (providing 0 , 129 , and 258 live seeds $/ \mathrm{m}^{2}$ ) were implemented to provide varying levels of competition from each species. The 2 rates of perennial species mixture were applied to allow evaluation of interactions between the species typically seeded at the mine and varying levels of rye and brome competition.

Mountain rye seed was from the Elk Creek accession grown at the Aberdeen Plant Materials Center, Aberdeen, Ida. The annual brome seed mixture was composed of $91 \%$ downy brome and $9 \%$ Japanese brome seed collected at the Decker Mine in 1986. The perennial species mixture consisted of 6 native cool-season perennial grasses: western wheatgrass (Agropyron smithii Rydb.), thickspike wheatgrass ( $A$. dasystachyum (Hook.) Scribn.), beardless wheatgrass ( $A$. inerme [Scribn. \& Smith] Rydb.), slender wheatgrass ( $A$. trachycaulum (Link) Malte), green needlegrass (Stipa viridula Trin.), and Indian ricegrass (Oryzopsis hymenoides [Roemer \& Schultes] Ricker); 2 native warm-season perennial grasses, alkali sacaton (Sporobulus airoides (Torr.) Torr.) and sideoats grama (Bouteloua curtipendula [Michx.] Torr.); and 1 leguminous forb sainfoin (Onobrychis viciaefolia Scop.) ${ }^{1}$. Seeding was accomplished on 8 October 1986 on a seedbed prepared by disk plowing. The annual bromes were broadcast seeded on appropriate plots, followed by sowing of mountain rye and the perennial species mixture with several passes of a tractor-drawn seeder-cultipacker.

\section{Biological Measurements}

Plant density and aboveground biomass were sampled in all subplots during 3 growing seasons (1987, 1988, and 1989). Density was estimated for all species in mid to late May each year by counting all live, rooted plants in 4 permanent $0.25 \mathrm{~m}^{2}(31 \times 80 \mathrm{~cm})$ quadrates randomly located in each subplot. Aboveground biomass was sampled at estimated peak standing crop in late June to early July each year by hand-harvesting all vegetation within four $0.50-\mathrm{m}^{2}(71 \times 71 \mathrm{~cm})$ quadrates per subplot. Harvested materials were dried at $60^{\circ} \mathrm{C}$ to constant weight before weighing.

Mountain rye seed production was estimated in 1987 by harvesting inflorescences within four $0.5-\mathrm{m}^{2}$ quadrates per subplot in late July. Samples were threshed and cleaned, seeds counted, weighed and viability determined using the tetrazolium (TZ) test (AOSA 1970).

Soil seedbank reserves of annual bromes (and other species) were sampled in September of 1986, 1987, and 1988. Four random samples ( 8 in 1988) of topsoil (15.9 $\mathrm{cm}^{2}$ surface by $5.1 \mathrm{~cm}$ depth) were core-extracted from each subplot, composited and frozen immediately following collection. Samples were later assayed for seed density using the soil extraction method of Malone (1967).

\footnotetext{
'Nomenclature follows Kartesz and Kartesz (1980).
}

Seeds of annual bromes and other species were identified and tested for viability using $\mathrm{TZ}$.

\section{Statistical Analyses}

All data were subjected to analysis of variance for a split-split block experimental design with perennial species treatments as the main plot, mountain rye rates as sub plots, and annual brome rates as sub-sub plots. Main and interactive effects of the 3 treatments were determined, as well as between year differences for certain data sets. If significant effects were apparent from the ANOVA, Tukey's method of pairwise comparison was used to determine differences among treatments or over time (Montgomery 1984), using $P<0.10$ as indicative of ecologically meaningful differences.

\section{Results}

\section{Mountain Rye Responses}

\section{Initial Establishment and Growth}

Following seeding in October 1986, mountain rye had germinated and was growing concurrently with annual bromegrasses by early November. Density of rye increased with rye seeding rate with each annual brome treatment in May of both the first (1987) and second (1988) growing seasons (Fig. 1). The response of rye

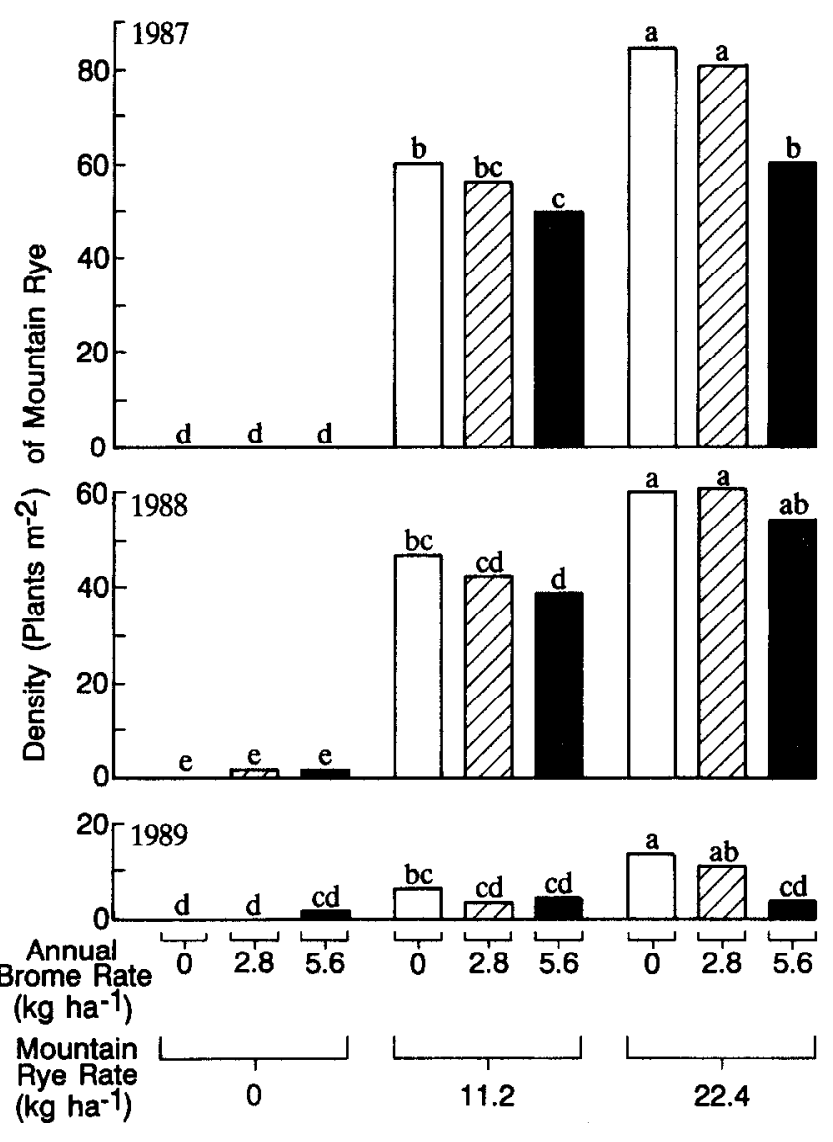

Fig. 1. Density of mountain rye (Secale montanum) at various seeding rates of mountain rye and annual bromegrass in May of the first (1987), second (1988), and third (1989) growing seasons. Within years bars superscripted with same letter are not significantly different at $\boldsymbol{P}<0.10$.

aboveground biomass to rye seeding rate was similar to that of density in 1987, but in 1988 all differences between the 11.2 and $22.4 \mathrm{~kg} / \mathrm{ha}$ rye rates disappeared (Fig. 2).

In 1987, both density (Fig. 1) and biomass (Fig. 2) of rye were lowest at the highest annual brome seeding rate within the 11.2 and $22.4 \mathrm{~kg} /$ ha rye seeding rate treatments, suggesting that rye was 

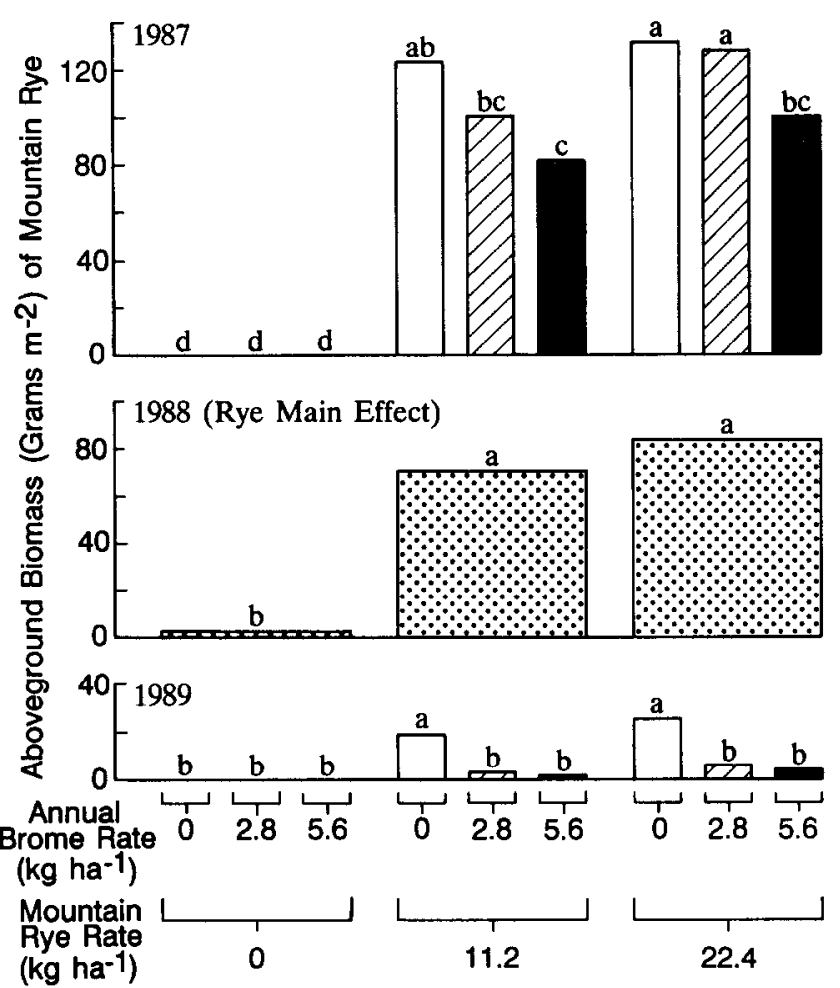

Fig. 2. Aboveground peak-standing biomass of mountain rye (Secale montanum) plants at various seeding rates of mountain rye and annual bromegrass during the first (1987), second (1988) and third (1989) growing seasons. Within years bars superscripted with same letter are not significantly different at $P<0.10$.

detrimentally affected by the highest level of bromegrass competition in the first growing season. This apparent competitive inhibition greatly diminished by 1988 , however, with no significant effect of brome seeding rates on rye biomass and a significant reduction of rye density only at the high brome rate within the moderate (11.2 $\mathrm{kg} / \mathrm{ha}$ ) rye rate treatment.

Analyses of year-to-year changes (Andersen 1989) indicated that both density and biomass of mountain rye significantly declined from 1987 to 1988 in nearly all treatment combinations. Figures 1 and 2 indicate approximately $90 \%$ across all treatments in rye density and biomass from 1988 to 1989 . Densities of remaining rye plants in 1989 increased with rye seeding rates only when annual brome was planted at 0 and $2.8 \mathrm{~kg} / \mathrm{ha}$ (Fig. 1). There were no rye seeding rate effects on rye density where brome was planted at 5.6 $\mathrm{kg} / \mathrm{ha}$. Even rye density at the $22.4 \mathrm{~kg}$ / ha rye rate was reduced with the heaviest brome rate. Maximum rye biomass was produced when rye was seeded at 11.2 and $22.4 \mathrm{~kg} / \mathrm{ha}$ and brome was not seeded. These relationships suggest that mountain rye was detrimentally affected by increasing levels of annual brome competition as the stand declined in 1989 .

\section{Recruitment}

Mountain rye produced substantial amounts of seed during its initial growing season (1987). Seed production increased with rye seeding rate from $588 \mathrm{seeds} / \mathrm{m}^{2}(51.5 \mathrm{~kg}$ of seed $/$ ha $)$ at the 11.2 $\mathrm{kg} / \mathrm{ha}$ rye rate, to $820 \mathrm{seeds} / \mathrm{m}^{2}(72 \mathrm{~kg}$ of seed $/ \mathrm{ha})$ at the $22.4 \mathrm{~kg} / \mathrm{ha}$ rye rate. Annual brome seeding rates had little influence on rye seed production. Rye seed produced averaged $81 \%$ laboratory viability.

Self-recruitment of rye from seed produced in 1987 was evaluated by analysis of density of new rye seedlings in October, 1987 and May, 1988 (Andersen 1989). Across all treatments, approxi- mately $14 \%$ of rye seeds had produced seedlings by October of 1987 , resulting in an average of 98 seedlings $/ \mathrm{m}^{2}$. Neither the greater seed production of the highest $(22.4 \mathrm{~kg} / \mathrm{ha})$ rye seeding rate, nor the variations in annual brome seeding rates affected the October seedling densities. Rye seedling densities declined from 98 seedlings $/ \mathrm{m}^{2}$ in October, 1987 to 42 seedlings $/ \mathrm{m}^{2}$ in May, 1988, indicating significant $(57 \%)$ seedling mortality irrespective of rye and brome seeding rate treatments (Andersen et al. 1990). Mountain rye produced little seed during the drought conditions of mid-1988, and no rye seedlings (new or surviving from the previous year's cohort) were evident by the end of 1988 or early in 1989 .

\section{Annual Bromegrass Responses \\ Initial Establishment and Growth}

Downy and Japanese hrome germination and seedling growth were conspicuous by early November, 1986. Japanese brome was the dominant annual grass in non-brome-seeded treatments due to its overwhelming preponderance in the soil seedbank (i.e., 325 seeds $/ \mathrm{m}^{2}$ as compared to only 4,26 , and 32 seeds $/ \mathrm{m}^{2}$ for downy brome, perennial grasses, and annual forbs, respectively). Conversely, brome-seeded treatments exhibited a much higher composition of downy brome due to the dominance of this species in the bromegrass seed $\operatorname{mix}(91 \%$ vs $9 \%$ for Japanese brome). Individual
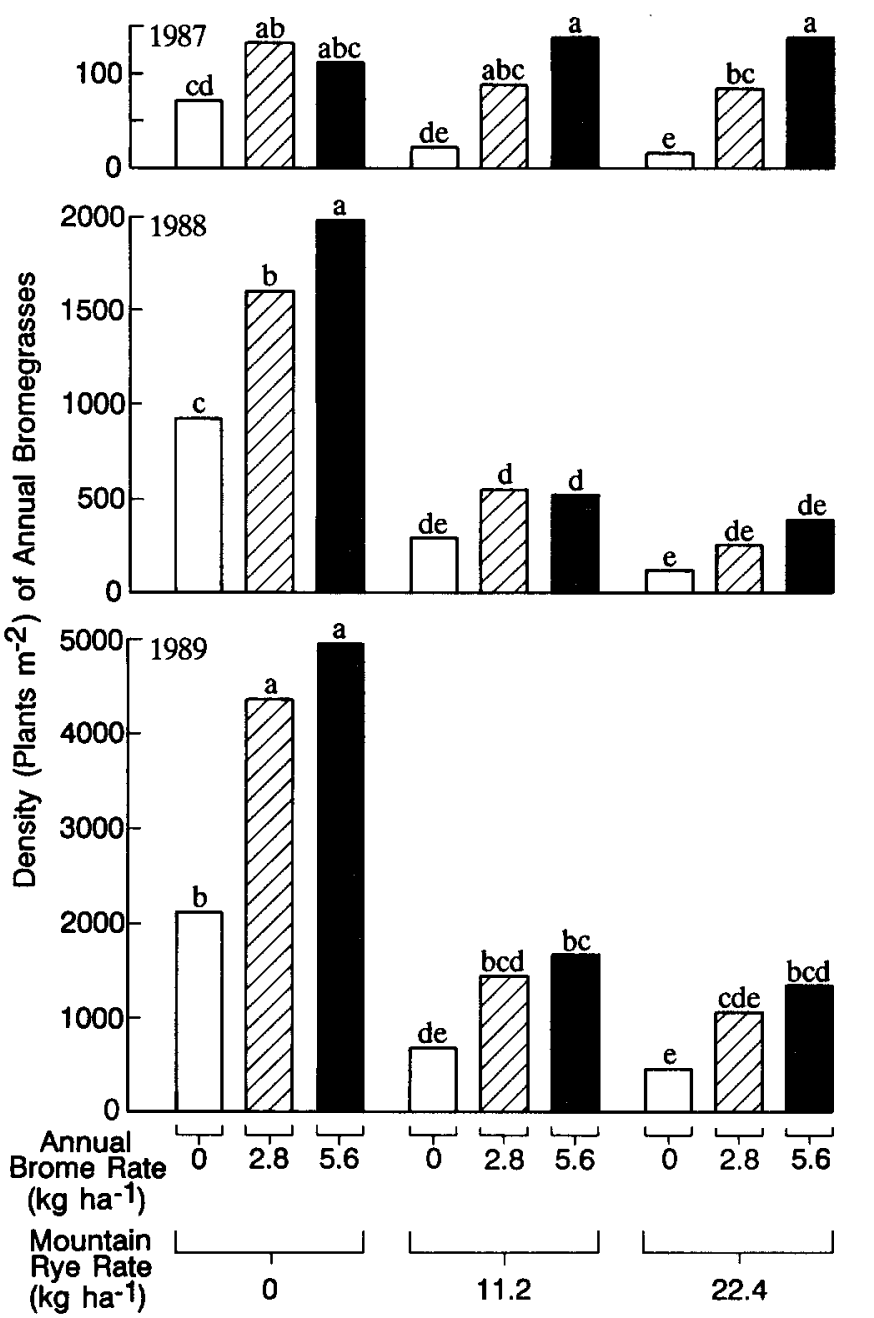

Fig. 3. Density of annual bromegrass (Bromus tectorum $+B$. japonicus) plants at various seeding rates of mountain rye and annual bromegrass in May of the first (1987), second (1988) and third (1989) growing seasons. (Note that scale varies among years). Within years bars superscripted with same letter are not significantly different at $P<0.10$. 


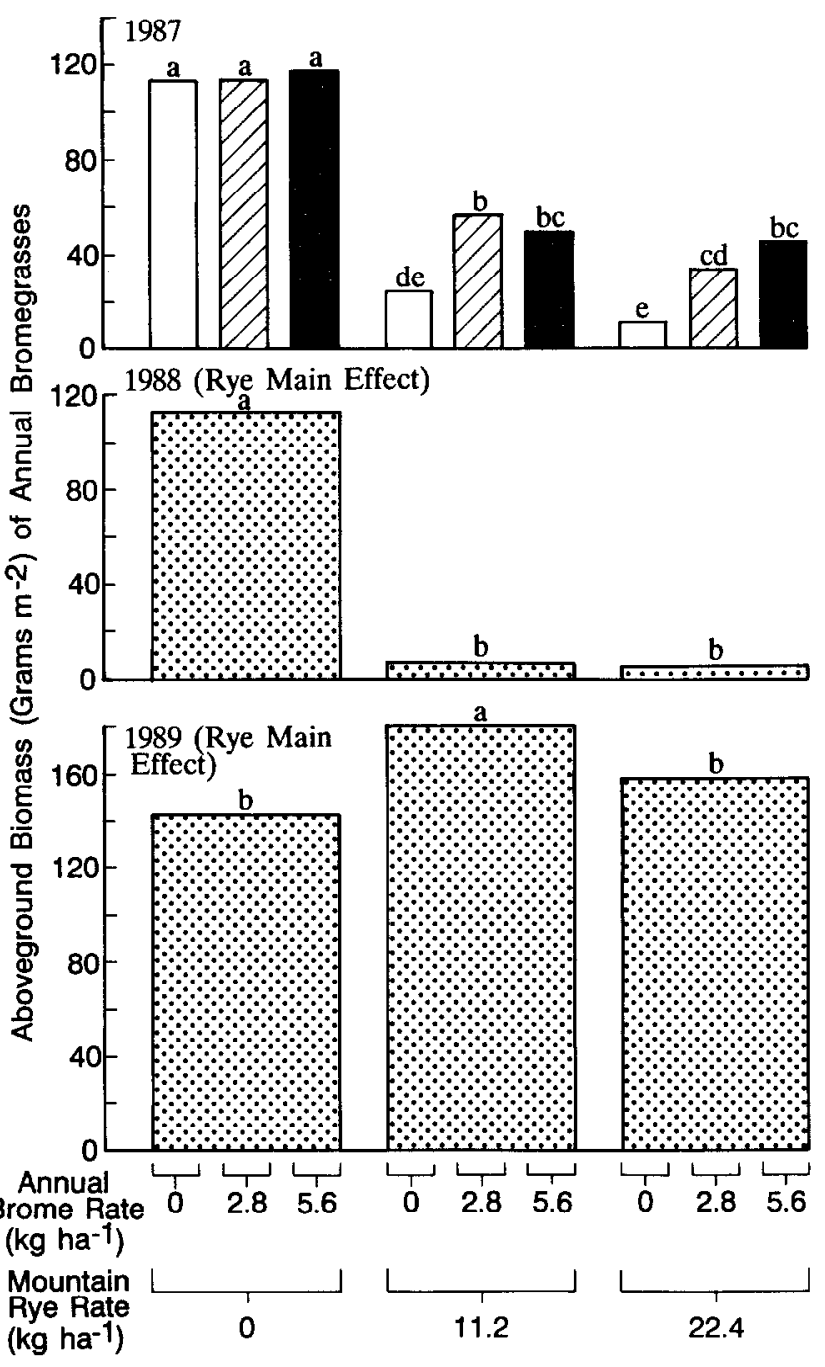

Fig. 4. Aboveground peak standing biomass of annual bromegrass (Bromus tectorum $+B$. japonicus) plants at various seeding rates of mountain rye and annual bromegrass during the first (1987), second (1988) and third (1989) growing seasons. Within years bars superscripted with same letter are not significantly different at $P<0.10$.

species data for downy and Japanese bromes are available in Andersen (1989). For purposes of brevity and ease of interpretation, this report will present combined data for these 2 fairly similar species (i.e., total annual bromegrass responses).

First year (1987) density and biomass of annual bromes usually increased from the 0 to $2.8 \mathrm{~kg}$ / ha brome seeding rates (Figs. 3 and 4). Differences between the 2.8 and $5.6 \mathrm{~kg} /$ ha brome rates were usually insignificant.

Increasing the seeding rate of mountain rye tended to reduce brome density only in the non-brome seeded treatment in 1987 (Fig. 3). In contrast, annual brome biomass significantly declined from the 0 to $11.2 \mathrm{~kg}$ / ha rye seeding rates within all brome rate treatments (Fig. 4); however, increasing the rye seeding rate from 11.2 to $22.4 \mathrm{~kg} /$ ha usually did not further reduce brome biomass.

Annual brome densities increased significantly from 1987 to 1988 in all treatments where rye was not seeded, but between-year differences in rye-seeded plots were usually not significant. In contrast, annual brome biomass significantly declined in most treatments from 1987 to 1988 , and the reduction was proportionately greatest in rye-seeded treatments (Andersen et al. 1990).

During 1988, significant effects of annual brome seeding rates were limited to a progressive increase in brome density from the 0 to $5.6 \mathrm{~kg} / \mathrm{ha}$ rates within the non-rye seeded treatment (Fig. 3); brome seeding rates had not significant effect on brome biomass. Seeded mountain rye significantly reduced the biomass and decreased the density of annual bromes in 1988, although no differences in the degree of reduction were evident between the 11.2 and $22.4 \mathrm{~kg} / \mathrm{ha}$ rye seeding rates (Figs. 3 and 4 ). The magnitude of brome biomass reduction by competing rye was generally greater than that for brome density reduction in 1988.

Annual brome densities increased dramatically from 1988 to 1989 in all treatments, with an $\sim 400 \%$ increase occurring in the $22.4 \mathrm{~kg} / \mathrm{ha}$ rye seeding rate. Brome biomass remained fairly constant in non-rye seeded treatments from 1988 to 1989 , but increased from less than $10 \mathrm{~g} / \mathrm{m}^{2}(1988)$ to over $160 \mathrm{~g} / \mathrm{m}^{2}(1989)$ in rye-seeded treatments. Treatment comparisons during the third year (1989) indicated a residual reduction of brome density by both rates of rye seeding despite the 1988 to 1989 increase in plant numbers. However, all suppression of brome biomass production by competing rye had disappeared in 1989 .

\section{Soil Seedbank}

The upper $5.1 \mathrm{~cm}$ of the soil prior to seeding in September, 1986 contained a total of 329 annual brome seeds $/ \mathrm{m}^{2}, 99 \%$ of which were Japanese brome. Soil densities of brome seeds increased significantly from late 1986 to late 1987 in non-rye seeded treatments (Andersen 1989). In rye-seeded treatments, however, 1986 to 1987 differences in brome seedbank density diminished with increasing rye seeding rate and became insignificant at the heaviest $(22.4 \mathrm{~kg} / \mathrm{ha})$ rye rate. Treatment comparisons during late 1987 indicated brome seed densities were similarly reduced by both rye seeding rates (Fig. 5).

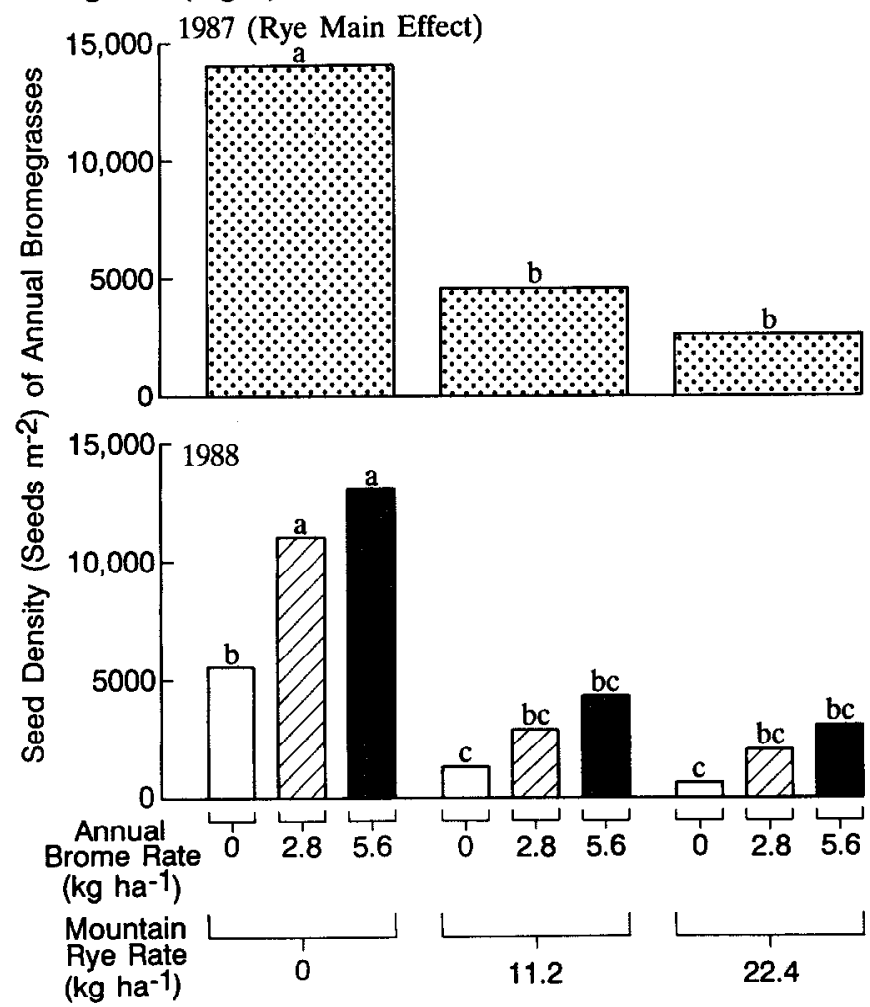

Fig. 5. Soil seedbank reserves of annual bromegrasses (Bromus tectorum + $B$. japonicus) at various seeding rates of mountain rye and annual bromegrass during September of the first (1987) and second (1988) growing season. Within each year, bars superscripted with the same letter are not significantly different at $\boldsymbol{P}<0.10$.

A significant rye-annual brome seeding rate interaction occurred for the brome soil seedbank densities during the late 1988 sampling period (Fig. 5). However, the brome seedbank was again similarly reduced in both mountain rye seeding rates (11.2 and $22.4 \mathrm{~kg} / \mathrm{ha})$ 

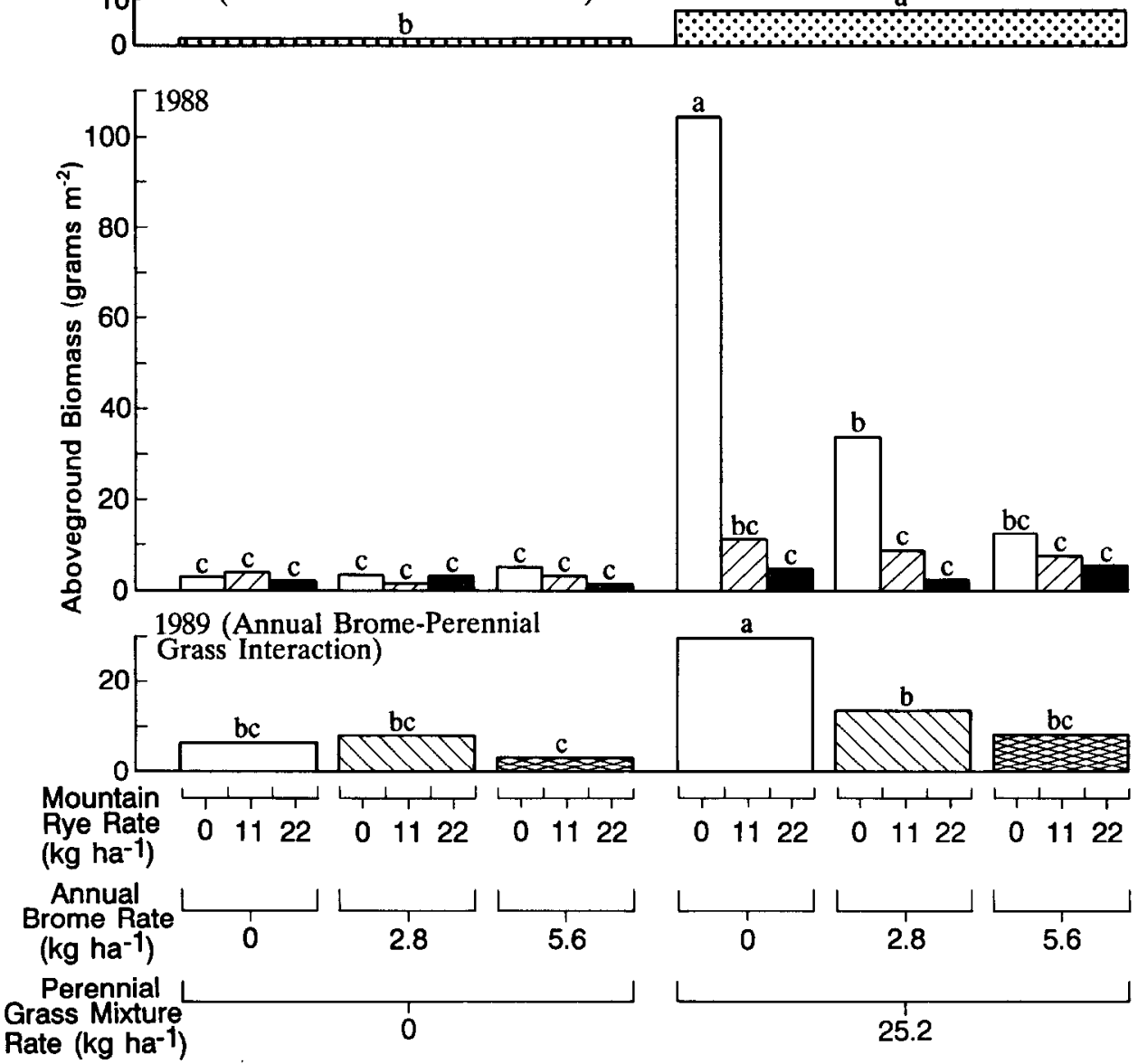

Fig. 6. Aboveground peak standing biomass of perennial grass (excluding mountain rye) at the indicated seeding rates for mountain rye, annual bromegrass or the perennial species mixture during the first (1987), second (1988) and third (1989) growing seasons. Within years, bars superscripted with the same letter are not significantly different at $P<0.10$.

for each brome rate. Brome seed densities also were similarly elevated at both brome seeding rates $(2.8$ and $5.6 \mathrm{~kg} / \mathrm{ha})$ where rye was not planted, but in rye-seeded treatments no differences in brome seedbank were apparent among brome seeding rates.

\section{Perennial Grass Responses}

Combined perennial grass species responses to treatments are presented, since the only non-grass species seeded (sainfoin) failed to establish on the site. Among seeded grasses, western, thickspike and slender wheatgrasses, and Indian ricegrass were the most prevalent species, although substantial volunteer establishment of crested wheatgrass $(A$. desertorum [Fisch.] Schultes) and, secondarily, needle-and-thread (Stipa comata Trin. \& Rupr.) occurred from seed introduced with the topsoil.

Andersen (1989) noted that initial perennial grass densities in grass-seeded plots were not detrimentally affected by increasing seeding rates of either annual bromes or mountain rye in 1987. Grass density declined significantly from the first (1987) to the second (1988) growing seasons only where bromes and rye were seeded at the heaviest rates ( 5.6 and $22.4 \mathrm{~kg} / \mathrm{ha}$, respectively), resulting in significantly lower grass density within those treatments during 1988.

Perennial grass biomass production was very limited in 1987. The only significant relationship was higher aboveground grass biomass in grass-seeded than non-grass-seeded plots (Fig. 6). In the second (1988) growing season, grass biomass became substantial only in plots not seeded to either mountain rye or annual bromes. In absence of mountain rye competition, grass biomass was similarly reduced by both annual brome seeding rates. Where moun- tain rye was seeded, grass biomass was massively and similarly reduced irrespective of rye or brome seeding rates.

Perennial grass density and biomass generally did not differ significantly among mountain rye seeding rates in the third (1989) growing season, suggesting an elimination of rye's inhibitory effect following its 1988 to 1989 diminution on the site. However, both annual brome seeding rates produced a residual similarly depressive effect on perennial grass biomass in grass-seeded plots (Fig. 6), while only the heaviest brome rate $(5.6 \mathrm{~kg} /$ ha) yielded depressed grass densities (data not shown).

\section{Discussion}

Mountain rye established quickly after fall seeding and exhibited remarkable productivity during the following year because of its seed germination ecology (Buman and Abernethy 1988), coolseason phenology and high growth rates (Buman et al. 1988). Although first season growth was suppressed somewhat by the highest level of annual brome competition, rye productivity was sizable at ca. $600 \mathrm{~kg} / \mathrm{ha}$ (roughly equal that of the bromes). Rye growth was relatively unaffected by any level of brome competition in the second growing season. Intraspecific rye competition may have been responsible for the lack of biomass production response by higher density stands from the high rye rate. Irregardless, these findings favor acceptance of our first working hypothesis that mountain rye would establish on the study site and exhibit vigorous growth concurrent with downy and Japanese bromes.

Our second hypothesis was that mountain rye would reduce growth and reproduction of annual bromes, and that this suppression would occur over a period of time sufficient to deplete brome 
seed reserves in the soil. Our results indicated that rye reduced annual brome establishment, productivity, and reproduction during the first 2 years when rye exhibited significant growth. However, the degree and duration of this brome suppression proved inadequate to meet the goal of longer-term brome control, as evidenced by recovery of brome productivity during the third growing season following the $90 \%$ die-off of rye in that year.

Annual brome densities during the second (1988) growing season averaged 1,482 plants $/ \mathrm{m}^{2}$ in the absence of mountain rye and between 297 and 452 plants $/ \mathrm{m}^{2}$ even when suppressed by mountain rye. While such densities may (Harris 1967) or may not (Romo and Eddleman 1987) be sufficient to reduce growth of perennial grasses, they certainly may produce sufficient seed to maintain soil seedbanks adequately for future brome recruitment. Brome soil seedbanks did not decline over time even in rye-seeded plots, but instead exhibited a 6-fold increase from $329 \mathrm{seeds} / \mathrm{m}^{2}$ in late 1986 to an average of over $2,000 \mathrm{seeds} / \mathrm{m}^{2}$ in late 1988 . Mountain rye did reduce the increase in annual brome soil seedbank during both the first 2 years (Fig. 5). Such a seedbank in 1988 readily explains the 3 to 4-fold increase in brome density that occurred in 1989 when direct competitive interference from rye was greatly reduced.

There was no depression of brome productivity in rye plots during 1989 despite a residual depression of brome density. From this we may infer that individual brome plants were more vigorous in the less dense stands of rye plots in 1989. This and the inverse relation between annual brome density and seed production (Young et al. 1969) suggest the likelihood of greatly increased brome seed production in rye plots in 1989 that could further increase brome densities in future years.

The above findings force rejection of our second working hypothesis. It is apparent that more than 2 years of annual brome suppression by rye will be necessary for longer-term brome control. The longevity of mountain rye therefore becomes an especially important concern.

Our third working hypothesis related to rye's longevity, and stated that this species would eventually decline due to its shortlived nature, allowing other seeded perennials to fully occupy the reclaimed site after adequate reduction of brome competition. Rye density declined greater than 10 fold during the third year (1989). Despite this, our third hypothesis must be rejected due to the previously noted lack of permanent brome control, and because the growth of perennial grasses did not prove greater in rye than in non-rye seeded treatments following rye dieback in 1989.

The rapid decline of mountain rye in this study contrasted with the previously noted persistence of this species on seeded rangelands in the intermountain region (Monsen and Shaw 1984). The decline in biomass production can be partially attributed to effects of summer drought and major grasshopper herbivory in 1988. However, the decline in density was visually evident during sampling in May of 1988, before the onset of drought and grasshopper problems, and thus may represent a population reduction due to several factors. The relative importance of rye's short-lived nature (Stutz 1972), interspecific competition, and/or inclement conditions (drought and grasshopper herbivory) during the second year (1988) as causal factors for the 1987 to 1989 decline of rye must remain conjectural. The decline in density early in 1988 lends strength to rye's short-lived nature as at least 1 important factor. The subsequent inclement conditions may have further weakened surviving rye plants to the point of producing the $90 \%$ mortality that occurred from 1988 to 1989.

Another important finding related to rye's brief persistence on the site was its lack of self-recruitment, despite excellent seed production and quality the first season and adequate weather for germination and seedling growth late in the first and early in the second seasons. Mountain rye is a relatively large-seeded species.
Seed produced in 1987 averaged 113,355 seeds $/ \mathrm{kg}$. Young et al. (1987) noted that large-seeded species frequently are not physiologically adapted for optimum germination at or near the soil surface, which could partially explain the low proportion (14\%) of rye seeds that produced seedlings in late 1987. Reasons for the poor survival of fall-germinated seedlings over winter and through the subsequent spring of 1988 are not readily apparent.

Sours (1983) suggested that mountain rye had great potential as a nurse (i.e., companion) crop for mixtures of other perennial species on disturbed sites. Mountain rye was sown as a companion crop with other perennials in the present study. Since effective companion crop species, in theory, should competitively retard weeds but not concurrently seeded perennials (Decker et al. 1973), responses of other seeded perennial grasses to mountain rye and rye-mediated annual brome competition are critical in evaluating the overall utility of mountain rye as a companion crop. Initial establishment densities of perennial grasses were not adversely influenced by any level of concurrent establishment of bromes or rye, but high levels of competition reduced perennial grass densities in the second growing season (Andersen 1989). Although rye reduced annual brome growth during the first 2 growing seasons, productivity of perennial grasses failed to respond positively to lowered brome competition. One reason for this lack of perennial grass response may relate to the only partial elimination of brome competition in rye-seeded plots. Monsen and Turnipseed (1990) suggested that reduction of annual brome density may not proportionately reduce brome competition due to the compensatory growth plasticity of individual plants that is inherent in these species. However, the major cause of poor perennial grass growth in rye-seeded plots was undoubtedly direct competition from rye itself. Indeed, perennial grass productivity appeared to be more detrimentally affected by rye than by annual brome competition during the second growing season, presumably because rye's period of active growth overlapped the later-season growth patterns of other perennial grasses. Although rye competition was virtually gone by the third growing season, the depression of perennial grass vigor by rye competition during the preceding 2 years was apparently sufficient to preclude any third season enhancement of grass productivity and competitiveness with annual bromes. Consequently, annual bromes increased dramatically during the third year and began, for the first time, to significantly suppress perennial grass productivity in rye-seeded plots.

The above findings confirm the often-recognized risks of companion cropping under arid/semiarid climatic regimes (Decker et al. 1973, DePuit 1988). Our research suggests that mountain rye might have greater potential as a preparatory (or, "pioneer") crop than as a companion crop under conditions at the study site. Various annual grain species have been used effectively on mined lands in the region for preparatory crop purposes of soil stabilization and, sometimes, weed control (Schuman et al. 1980, 1985). This alternative use has been suggested previously for mountain rye (Sours 1983). Under a preparatory crop strategy, rye could be seeded for a number of successive 2-year rotations hopefully sufficient for more sustained reduction of brome growth, seed production and, consequently, seedbank depletion. It is possible that the length of rotations could be increased if weather regimes favor longer persistence of rye and / or if a longer-lived accession of rye is identified for use. The rotations eventually would be followed by interseeding of desired perennial species in an environment with reduced competition stress from both rye and annual bromes. The effectiveness and practicality of this approach remain to be evaluated.

\section{Conclusions}

Results of this research favor the utility of mountain rye as a 
species capable of rapid, vigorous establishment and significant reduction of downy and Japanese bromes through the duration of its dominance on a brome-infested minesite. However, we must conclude that use of mountain rye as a companion crop was not effective for sustained control of annual bromes and enhancement of permanent revegetation because of its short persistence on the site and negative to neutral effects on other seeded perennial grasses. The effectiveness of rye for short-term brome reduction, however, should encourage further research on different rye seeding strategies for longer-term brome control. The establishment ease, vigorous growth, and short longevity of mountain rye suggest that it may have potential for uses other than weed control alone, such as soil stabilization, organic matter enrichment, and related pioneer plant functions often assumed by other, less desirable species during secondary succession on disturbed lands.

\section{Literature Cited}

Allen, E.B. 1989. Some trajectories of succession in Wyoming sagebrush grassland: implications for restoration. P. 89-112. In: E.B. Allen (ed.). The Reconstruction of Disturbed Arid Lands: An ecological Approach. Westview Press, Boulder, Colo.

Allen, E.B., and D.H. Knight. 1984. The effects of introduced annuals on secondary succession in sagebrush-grassland, Wyoming. Southwestern Natur. 29:407-421.

Andersen, M.R. 1989. Competitive relationships of mountain rye and annual bromegrasses on a semiarid mine site. M.S. Thesis, Univ. Wyoming, Laramie.

Andersen, M.R., E.J. DePuit, R.H. Abernethy, and L.H. Kleinman. 1990. Suppression of annual bromegrasses by mountain rye (Secale montanum) on semiarid mined lands. P. 47-55. In: Proc., Symp. on Cheatgrass Invasion, Shrub Die-Off and Other Aspects of Shrub Biology and Management. USDA Forest Serv. Gen. Tech. Rep. INT-276, Ogden, Utah.

AOSA. 1970. Tetrazolium testing handbook for agricultural seeds. D.F. Grabe (ed.) Assoc. of Off. Seed Anal. Handb. 29.

Buman, R.A., and R.H. Abernethy. 1988. Temperature requirements for mountain rye, Hycrest crested wheatgrass and downy brome germination. J. Range Manage. 41:35-39.

Buman, R.A., S.B. Monsen, and R.H. Abernethy. 1988. Seedling competition between mountain rye, 'Hycrest' crested wheatgrass and downy brome. J. Range Manage. 41:30-34.

Decker, A.M., T.H. Taylor, and C.J. Willard. 1973. Establishment of new seedings. P. 384-395. In: M.E. Heath, D.S. Metcalfe and R.F. Barnes (eds.) Forages: The Science of Grassland Agriculture (3rd edition), Iowa State Univ. Press, Ames.

DePuit, E.J. 1988. Productivity of reclaimed land-rangeland. P. 93-129. In: L.R. Hossner (ed.) Reclamation of Surface-Mined Lands, Volume II. CRC Press, Boca Raton, Fla.

Evans, R.A. 1961. Effects of different densities of downy brome (Bromus tectorum) on growth and survival of crested wheatgrass (Agropyron desertorum) in the greenhouse. Weeds 9:216-223.
Evans, R.A., H.R. Holbo, R.E. Eckert, and J.A. Young. 1970. Functional environment of downy brome communities relation to weed control and revegetation. Weed Sci. 18:154-162.

Harris, G.A. 1967. Some competitive relationships between Agropyron spicatum and Bromus tectorum Ecol. Monogr. 37:89-111.

Harris, G.A., and A.M. Wilson. 1970. Competition for moisture among seedlings of annual and perennial grasses as influenced by root elongation at low temperatures. Ecology 51:530-534.

Hulbert, L.C. 1955. Ecological studies of Bromus tectorum and other annual bromegrasses. Ecol. Monogr. 25:181-213.

Kartesz, J.T., and R. Kartesz. 1980. A synonymized checklist of the vascular flora of the United States, Canada and Greenland, Volume II: the biota of North America. Univ. N. Carolina Press, Chapel Hill.

Mack, R.N. 1981. Invasion of Bromus tectorum into western North America: an ecological chronicle. Agro-Ecosystems 7:145-165.

Malone, C.R. 1967. A rapid method for enumeration of viable seed in soil. Weeds 15:381-382.

Monsen, S.B., and N. Shaw. 1984. Secale montanum-a useful grass for western rangelands. Abst. 37th Annu. Meeting, Soc. Range Manage., Rapid, City, S.D.

Monsen, S.B., and D. Turnipseed. 1990. Seeding forage kochia onto cheatgrass-infested rangelands. p. 66-71. In: Proc., Symp. on Cheatgrass Invasion, Shrub Die-Off and Other Aspects of Shrub Biology and Management. USDA Forest Serv. Gen. Tech. Rep. INT-276, Ogden, Utah.

Montgomery, D.C. 1984. Design and analysis of experiments. John Wiley and Sons, N.Y.

Payne, G.F. 1973. Vegetative rangeland types in Montana. Montana. Agr. Exp. Sta. Bull. 671, Bozeman. Mont.

Romo, J.T., and L.E. Eddleman. 1987. Effects of Japanese brome on growth of bluebunch wheatgrass, junegrass and squirreltail seedlings. Reclam. and Reveg. Res. 6:207-218.

Schuman, G.E., E.M. Taylor, F. Rauzi, and G.S. Howard. 1980. Standing stubble versus crimped straw mulch for establishing grass cover on mined lands. J. Soil and Water Conserv. 35:25-27.

Schuman, G.E., E.M. Taylor, F. Rauzi, and B. Pinchak. 1985. Revegetation of mined land: influence of topsoil depth and mulching method. $J$. Soil and Water Conserv. 40:249-252.

Sours, J.M. 1983. Characteristics and uses of important grasses for arid western rangelands. p. 90-94. In: S.B. Monsen and N. Shaw (eds.) Managing Intermountain Rangelands-Improvement of Range and Wildlife Habitats. USDA Forest Serv. Gen. Tech. Rep. INT-157, Ogden, Utah.

Stewart, G., and A.C. Hull. 1949. Cheatgrass (Bromus tectorum) an ecological intruder in southern Idaho. Ecology 30:58-74.

Stutz, H.C. 1972. On the origin of cultivated rye. Amer. J. Bot. 59:59-70.

Young, J.A., R.A. Evans, and G.J. Cluff. 1987. Seeding on or near the surface of seedbeds in semiarid environments. P. 57-61. In: G.W. Frasier and R.A. Evans (eds.) Proc., Symp. on Seed and Seedbed Ecology of Rangeland Plants. USDA-ARS, Tucson, Ariz.

Young, J.A., R.A. Evans, and R.E. Eckert. 1969. Population dynamics of downy brome. Weed Sci. 17:20-26. 